\title{
INVESTIGATION OF METAL FLOW INSIDE SHAPE GROOVES DURING ROLLING OF CHANNELS WITH LARGE DEFORMATIONS
}

\author{
MichaŁ DZIEDZIC*, StanisŁaW TurCZyn, Zbigniew KuŹMińSKI \\ AGH University of Science and Technology, al. Mickiewicza 30, 30-059 Krakow, Poland \\ *Corresponding author: dziedzic@agh.edu.pl
}

\begin{abstract}
The aim of the following study was to introduce new roll pass design of channels into industrial practice. The necessity of usage of a greater charge stock has caused need for applying rolling with large deformations. The main task during modelling was a proper filling of the grooves in the two high and universal rolling stands. Apart from that, the location of grooves in the rolls assembly, selection of reduction in all parts of the groove and the stress/strains distributions in the roll bite were calculated. At first, the series of plastometric tests were performed to obtain characteristic data of the rolled steel, which were required for the subsequent calculations. During computer simulation all passes were calculated until accurate profiles were obtained, i.e. until the rolled material properly filled all parts of the grooves. Both axial and vertical roll forces were checked as to whether they were below permissible values. Obtained results are presented for several passes of channels rolling. Commercial code Abaqus Explicit were chosen for realization of the fully three-dimensional model. Finally, the results of numerical modelling were used for working out of new roll pass design for rolling sections with large deformations, which was applied in industrial conditions.
\end{abstract}

Key words: Channels rolling, Numerical modelling, FEM, Roll pass design

\section{INTRODUCTION}

Among a many aspects of hot rolling process of complex steel sections, some are particularly critical, such as metal flow inside all parts of the roll grooves (Kopp \& Koch, 1997). The material behavior and prediction of actual spread, distribution of temperature and residual stresses are also significant parameters, which can be evaluated during designing of the rolling process (Kawalla, 2010; Schmitz \& Prahl, 2012). The final shape and comprehensive properties of the products, i.e. microstructure and mechanical properties are directly affected by process design, especially during rolling of complex steel shapes like channels, beams, rails etc. (Hensel et al., 1996). These steel sections belong to highly demanded rolled products due to their utilization properties. The production of sec- tions is very profitable, but on the other hand, the rolling process in the two high stands or 4-high universal group is very sophisticated, mainly due to risk of improper metal flow and the very high horizontal and vertical rolling forces (Harrer et al., 1996; Turczyn et al., 2014; Turczyn \& Dziedzic, 2016).

In the hot rolling processes, thermal condition can be important. The effect of heat transfer during sections rolling was studied in work (Lee \& Kim, 2001) and these results showed that this factor has a small effect on geometry and energy results due to the fact that time of contact length between the stock and rolls is very short. Moreover, the oxide layer on the surfaces of stock and roll decreases the heat transfer between these two surfaces.

The aim of the present work was to develop a new roll pass design of channels and introduce it into industry. The necessity of usage of a charge stock with 
a greater cross section has caused an applying of the new rolling schedule with large deformations.

The explicit dynamic FE software Abaqus was used to simulate hot rolling of channels using twohigh and four-high passes, according to continuous rolling process in Celsa Huta Ostrowiec. The heat transfer is not considered in each stand, but the stock temperature is updated in the next passes. Due to good agreement between numerical and experimental results in the previous and present grant, these numerical simulations have been applied to predict the values of the most important rolling parameters of channel rolling using the developed roll pass design.

\section{NUMERICAL MODELLING OF CHANNELS ROLLING}

The model is based on the industrial conditions of continuous rolling line in Medium Section Mill, existing in Celsa Huta Ostrowiec. The rolling process of $300 \mathrm{~mm}$ in height channels takes place in 15 passes, first of all in two-high stands and then in four-high ones. In this work a full three-dimensional finite element model is applied. The pure Lagrangian formulation was considered in the analysis. Since this work was limited to the practical application in the industry, the finite element model was used for mechanical application, i.e. stresses, strains distribution and value of deformations were mainly computed. The process was considered as adiabatic and the heat transfer in roll bite was neglected. Therefore explicit, dynamic and adiabatic conditions were applied to solve this transient problem.

\subsection{The rolls and stock model}

For performing the numerical computation of the rolling process of sections in two-high and four-high stands, a three dimensional models were signed in a CAD-type program. The solid objects, whose bodies were then transformed into finite element mesh have been applied. For the rolls model, a three-dimensional solids mesh has been used, see figure 1 .
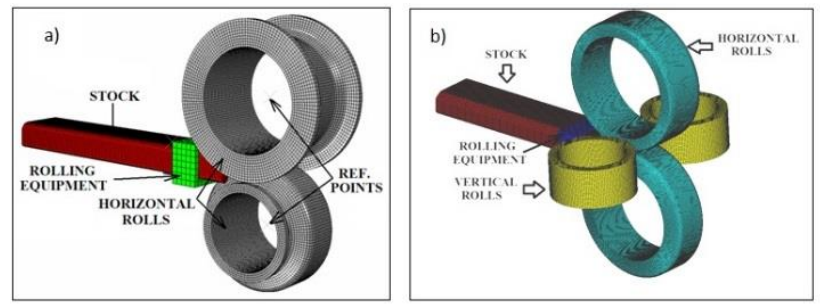

Fig. 1. A finite element mesh generated for the rolls and stock, a) two-high stands, $b$ ) universal stands.
Since the deformation of the rolls and rolling equipment are within the elastic limit and are very small compared to the large plastic deformation of the stock, the rolls and rolling equipment are considered as a rigid body. The rolled stock is assumed as homogeneous and isotropic material with no porosities. Stress curves of S355 grade steel were fitted to an equation, which was a function of strain, strain rate and temperature.

\subsection{Flow curve of rolled steel S355}

The accuracy of calculations performed by using Abaqus solver is dependent on the accurate determination of the material properties used in the analysis. Conducted experimental studies aimed at the determination of the effect of strain, strain rate and temperature on the yield stress for S355 grade steel. Hot plastometric tests were performed using the torsion plastometer.

Flow stresses for steel obtained from the tests for the strain rate equal to $2 \mathrm{~s}-1$ and different temperatures are presented in figure. 2. From the flow stress shown in figure 3 , a distinct effect of strain and strain rate on the value of $\sigma p$ can be observed.

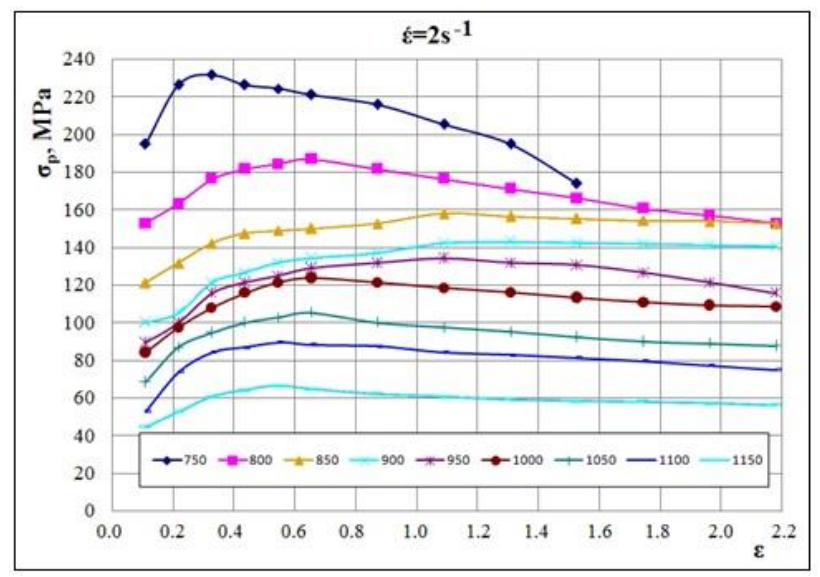

Fig. 2. Flow stress for $S 355$ grade steel as deformed at strain rate $\left.2 s^{-1}\right)$.

\subsection{Boundary conditions for the process of channels rolling}

Three-dimensional, deformable, reduced integration, and linear hexahedral (brick) element (C3D8R) is used to model the stock. For simulation of the rolls, R3D4 element is used that is a four-node element suitable for modeling the three dimensional rigid bodies whose behavior is a function of a specified point, named reference point. The surface between roll and stock is defined as a contact pair that consists of pe- 


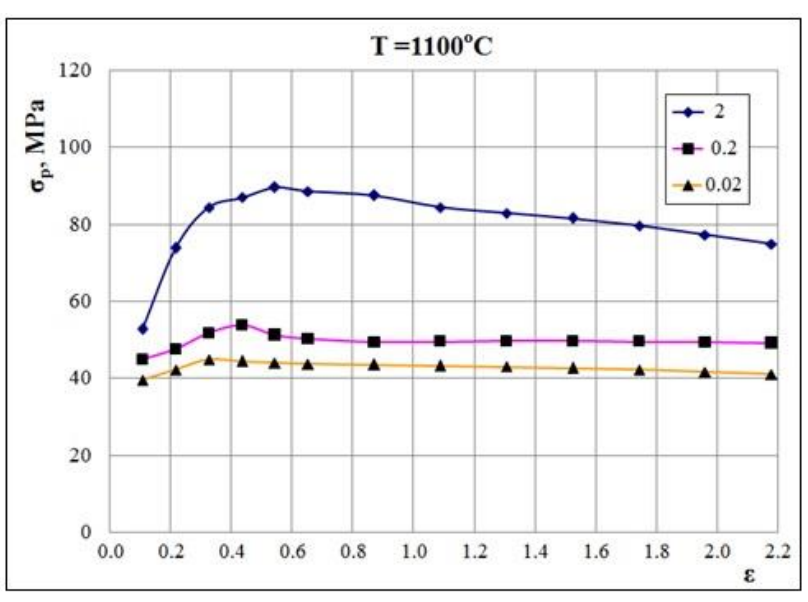

Fig. 3. Flow stress for S355 grade steel as deformed at different strain rate.

nalty contact enforcement method. The Coulomb friction model is considered as the contact algorithm. Mass scaling is not used in the analysis (large amount of mass scaling can predict the correct deformed shape, however, it may adversely affect other parameters that are influenced by inertia, e.g., stress, velocity, etc). Because of large deformations happening during the channels rolling in the shape grooves, ALE adaptive meshing provides mesh distortion control. According to work (Lee \& Kim, 2001), the heat conduction to rolls in each pass is considered to be constant, but it is updated between the stands and therefore mechanical behavior of material in each pass is different from others. The rolling process of the analysed channel includes 15 passes but the most critical were passes from 6 to 9 and therefore these passes have been exactly analysed and presented in this paper. The temperature of entering stock into pass 6 is considered to be $1195^{\circ} \mathrm{C}$ and the temperature at the exit from pass 9 is $1130^{\circ} \mathrm{C}$. The rolls are constrained to rotate only in one direction and the magnitude of rotation is based on the applied rolling technology. These data are used as a boundary condition in the finite element model. The velocity and temperature of the stock at the entry to the stands are used as initial conditions in the model, see table 1.

Table 1. Boundary conditions applied in the FEM of hot rolling of channel in the passes No. $6 \div 9$.

\begin{tabular}{|c|c|c|c|c|}
\hline $\begin{array}{c}\text { Pass } \\
\text { no. }\end{array}$ & $\begin{array}{c}\text { Tempe- } \\
\text { rature } \\
\mathrm{oC}\end{array}$ & $\begin{array}{c}\text { Coefficient } \\
\text { of friction }\end{array}$ & $\begin{array}{c}\text { Entrance } \\
\text { speed, } \\
\mathrm{m} / \mathrm{s}\end{array}$ & $\begin{array}{c}\text { Rolls } \\
\text { speed, } \\
\mathrm{m} / \mathrm{s}\end{array}$ \\
\hline 6 & 1195 & 0.4525 & 0.50 & 0.63 \\
\hline 7 & 1175 & 0.4625 & 0.63 & 0.72 \\
\hline 8 & 1154 & 0.473 & 0.72 & 0.81 \\
\hline 9 & 1130 & 0.435 & 0.81 & 0.90 \\
\hline
\end{tabular}

The plastic flow curves of the stock were calculated based on the torsion test and grouped in sets of strain, strain rate and temperature, in ascending order. As an example of the carried out 3D finite element simulations, the scheme of pass No. 8 is shown in figure 1a and for pass No. 9 (universal stand) in figure $1 b$.

\section{RESULTS OF NUMERICAL MODELLING}

The complexity of phenomena taking place in hot rolling of sections creates a wide range of possibilities for controlling the process parameters and groove filling. Groove filling and the entire process of channels rolling is very sensitive to small variations of rolling parameters. However, the principal factor is to ensure right metal flow in all part of the grooves. Example groove filling during hot rolling of the channels is presented in figures 4-7. As can be seen in these figures, right filling of the newly designed grooves by the metal is observed. Groove 7 characterizes mild radius of the transition between web and flange. An application of smaller radius in this place may cause dangerous cracks of the rolls.

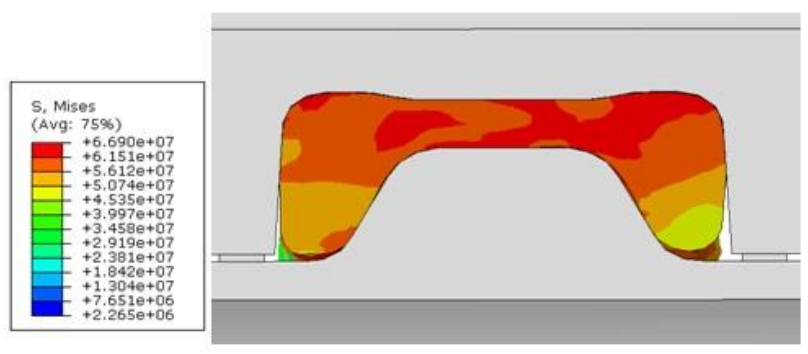

Fig. 4. Shape of the stock and distribution of von Misses stress in the strip during rolling of channels in the groove No. 6.

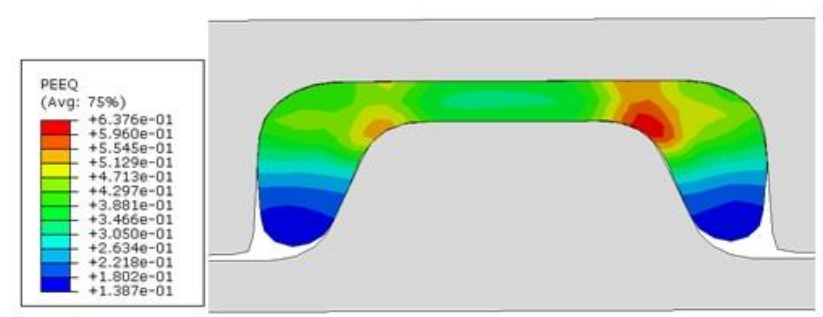

Fig. 5. Shape of the stock and distribution of equivalent plastic strains during rolling of channels in the groove No. 7.

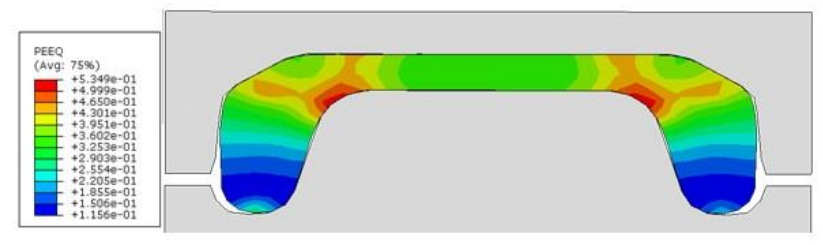

Fig. 6. Shape of the stock and distribution of equivalent plastic strains during rolling of channels in the groove No. 8 . 


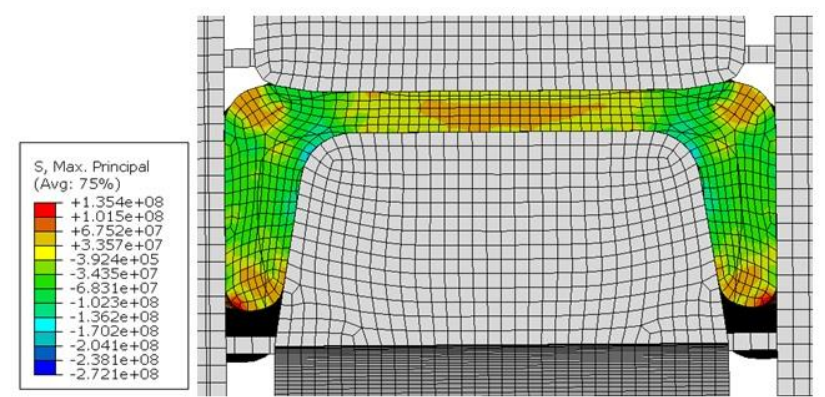

Fig. 7. Shape of the stock and distribution of maximal principal stresses during rolling of channels in the groove No. 9.

As shown in figures 5 and 6 , the equivalent plastic strain of workpiece along the width of the groove is highly inhomogeneous during rolling and it has maximal value at the bottom corners of the groove and minimal value in the end parts of the flanges. Reduction of the wall thickness in the middle of the groove (web creation) is much larger than reduction of the flanges, especially in the seventh and eighth pass. There is high compression in the center of the groove (web) where the elongation is maximal; on the contrary to the sidewall of the groove, where compression is relatively small. In the first universal stand, where groove is formed by pairs of horizontal and vertical rolls, figure 7 , it is observed different situation. Distinction between the tension stresses in the web and compression stresses in the central part of the flanges is not highly diversified. Figure 8 shows the shapes of the rolling stock at the exit from the pass No. 8 in universal stand. Figure 9 shows the shapes of the rolling stock at the exit from pass No. 9.

While the top roll has flattened horizontal part of the groove, the bottom roll forms the C-shape of the section. Due to the unsymmetrical deformation and differences of rolls radius the section is leaving the pass under the given process conditions. It can moves away upwards, horizontal or downwards. As shown in figures $8 \mathrm{a}$ and $9 \mathrm{a}$, the rolling stock leaves the gap irregularly. The top part of the section is clearly more elongated than the bottom one, with the consequence that the material moves away downwards. Such situation is dangerous for roll accessories and was changed during roll pass design. Balancing of the groove neutral line with the rolling line causes that the material moves away straight, figures $8 \mathrm{~b}$ and $9 \mathrm{~b}$.

Table 2 presents roll force and torque registered during numerical modelling of channels rolling in the roughing and intermediate groups of mill stands (No. $6 \div 9$ ). The forces are used mainly to control the strength of each rolls. Due to redesign of grooves shape the roll forces has been reduced to less than $7800 \mathrm{kN}$. As illustrated in table 2 roll separating force in stand No. 9 is distinctly lower than in other stands because the reduction factor in this stand is less than in other passes. The total rolling torque in all passes was reduced to less than $600 \mathrm{kNm}$.

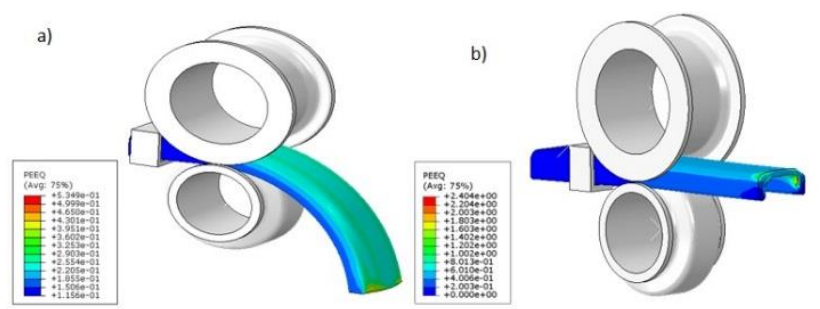

Fig. 8. Strip shape at the exit from of the groove No. 8: a) wrong location of the rolling line, b) balance of the groove neutral line with the rolling line.

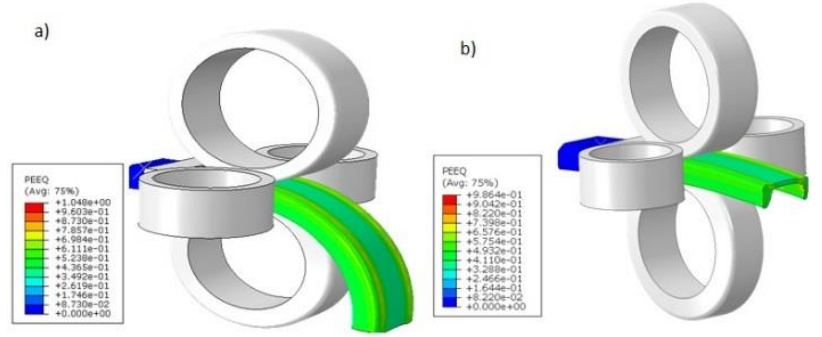

Fig. 9. Strip shape at the exit from of the groove No. 9: a) wrong location of the rolling line, $b$ ) balance of the groove neutral line with the rolling line.

Using the results of numerical modelling, the roll pass design for channels rolling has been redesigned and applied in industrial conditions. In a consequence, it have been obtained channels (UPN300) of right shape (figure 10) and good mechanical properties. The rolling process of steel sections is characterized by large deformations. Apart from that, the results of the calculation contributed to the better understanding of the flow patterns in the roll grooves, as well as distribution stresses and strains in the material being rolled.

Table 2. Roll force and torque obtained for the passes No. $6 \div 9$ during modelling of channels rolling from S355 grade steel.

\begin{tabular}{|c|c|c|c|c|c|c|}
\hline $\begin{array}{c}\text { Pass } \\
\text { No. }\end{array}$ & $\begin{array}{c}\text { Temperature } \\
{ }^{\circ} \mathrm{C}\end{array}$ & $\begin{array}{c}\text { Roll seperating force } \\
\mathrm{kN}\end{array}$ & $\begin{array}{c}\text { Axial force } \\
\mathrm{kN}\end{array}$ & $\begin{array}{c}\text { Upper roll torque } \\
\mathrm{kNm}\end{array}$ & $\begin{array}{c}\text { Lower roll torque } \\
\mathrm{kNm}\end{array}$ & $\begin{array}{c}\text { Total torque } \\
\mathrm{kNm}\end{array}$ \\
\hline 6 & 1195 & 7760.0 & 1880.3 & 167.18 & 374.84 & 542.02 \\
\hline 7 & 1175 & 7740.0 & 1717.2 & 167.18 & 375.84 & 543.02 \\
\hline 8 & 1154 & 7070.0 & 476.9 & 73.88 & 234.91 & 308.79 \\
\hline 9 & 1130 & 3790.0 & - & 166.80 & 424.75 & 591.68 \\
\hline
\end{tabular}




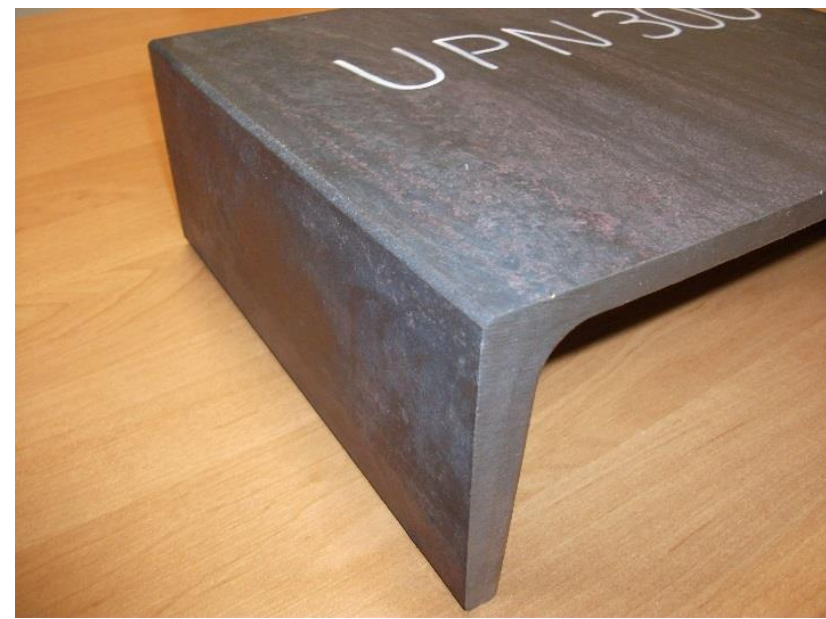

Fig. 10. Template of the channel UPN 300 after industrial rolling with the use of new roll pass design.

\section{CONCLUSIONS}

1. In the present investigation, hot rolling of channels has been modelled by utilizing 3D finite element method. The main task during modelling was a proper filling of the grooves in the two-high and four-high rolling stands. Apart from that the location of grooves in the rolls assembly, selection of reduction in all parts of the groove and the stress/strains distributions in the roll bite were calculated.

2. The results obtained from numerical modelling have been compared with the experimental measurements and the good agreement between them is observed regarding the material flow in the grooves.

3. Initial rolling deficiencies like stock bending at the roll exit has been solved by modifying the groove position in the roll assembly, so that a safe rolling process can be guaranteed within the requested tolerances of the product. It was proved during industrial operations.

4. The obtained results are presented for several passes of channel UPN300 rolling. Finally, the results of numerical modelling were used for working out of final roll pass design for sections rolling with large deformations and were applied in industrial conditions. In a consequence, the channels (UPN300) of right shape and good mechanical properties were manufactured.

\section{ACKNOWLEDGMENTS}

This research has been founded by European Union in the area of POIR project (Granted No. 01.02.00-00-0179/16-00). We also thank the ACC Cyfronet AGH for the computational support of this investigation performed in part by PLGrid Infrastructure.

\section{REFERENCES}

Harrer, O., Buchmayr, B., Riedl, A., 2010, Simulation des Walzens von Rippenplatten UIC60-0, MEFORM 2010 Tagungsband, Freiberg, 226-237.

Hensel, A., Lehnert, W., Krengel, R., 1996, Close-to-net-shape casting and rolling sections, Der Kalibreur, 57, 41-46.

Kawalla, R., 2010, Development of simulation software for the analysis of multi stage hot rolling of strips and wire rod, METABK, 49(3), 175-179.

Kopp, R., Koch, M., 1997, The Application of numerical simulation methods to improve the process transparency in complex rolling operation, Der Kalibreur, 58, 33-38.

Lee, Y, Kim, Y.H., 2001, Approximate analysis of force in a round-oval-round pass rolling sequence, Journal of Material Processing Technology, 113, 124-130.

Schmitz, G. J., Prahl, U., 2012. Integrative computational materials engineering: Applications of a modular simulation platform, Wiley-VCH Verlag GmbH \& Co. KGaA, 148.

Turczyn, S., Dziedzic, M., Kuźmiński, Z., 2014, Metal flow during rolling of long products with use of compound grooves. Proc. 9th Int. Conf., ICIT \& MPT, Lubljana, 327-341.

Turczyn, S., Dziedzic, M., 2016, Assessment of metal flow during rolling of sheet piles. Der Kalibreur, Heft, 77, 56-63.

\section{BADANIA PLYNIECIA METALU W \\ WYKROJACH KSZTALTUJACYCH DO WALCOWANIA CEOWNIKÓW Z DUŻĄ INTENSYWNOŚCIĄ ODKSZTALCENIA}

\section{Streszczenie}

W artykule przedstawiono badania numeryczne płynięcia metalu podczas walcowania na gorąco ceowników z dużą intensywnością odkształcenia. Analizę numeryczną zaprojektowanych wykrojów kształtowych wykonano za pomocą metody Dynamic Explicit, wykorzystując komercyjne oprogramowanie Abaqus w wersji 6.19. Materiałem zastosowanym w procesie walcowania była stal S355, a jej krzywe umocnienia zaimplementowano do oprogramowania po wykonaniu badań plastometrycznych na plastometrze skrętnym. Przeprowadzone symulacje numeryczne w warunkach przestrzennego stanu odkształcenia pozwoliły na wyznaczenie parametrów siłowo-energetycznych (nacisków całkowitych i momentów walcowania), określenie rozkładu intensywności naprężeń i odkształceń oraz płynięcia metalu w poszczególnych wykrojach kształtujących.

Wykonane badania numeryczne pokazały również, że niewłaściwe umiejscowienie w złożeniu walców poprawnie zaprojektowanego wykroju może powodować wyginanie pasma w dół (tzw. 
docisk górny). Prawidłowe usytuowanie wykroju w walcach poprzez odpowiednie usytuowanie linii neutralnej wykroju względem linii walcowania zapewniło bardziej równomierny i stabilny proces walcowania.

Uzyskane w rezultacie badań wyniki pozwoliły na przemysłowe wdrożenie technologii walcowania na gorąco ceowników przy stosowaniu dużej intensywności odkształcenia.

Received: December 4, 2019

Received in a revised form: December 15, 2019.

Accepted: December 16, 2019. 